\title{
SOIL-STRUCTURE INTERACTION ANALYSES TO LOCATE NUCLEAR POWER PLANT FREE-FIELD SEISMIC INSTRUMENTATION
}

\author{
Dr. James J. Johnson ${ }^{1}$, Dr. Jon P. Ake ${ }^{2}$, Oleg R. Maslenikov ${ }^{1}$, Roger M. Kenneally ${ }^{3}$ \\ ${ }^{1}$ James J. Johnson and Associates, Alamo, CA \\ ${ }^{2}$ Senior Seismologist, US Nuclear Regulatory Commission, Washington, D.C. \\ ${ }^{3}$ Consultant, Seminole, FL
}

\section{ABSTRACT}

The recorded earthquake ground motion at the nuclear power plant site is needed for several purposes. US Nuclear Regulatory Commission (NRC) Regulatory Guide 1.12, NRC (1997a), describes acceptable instrumentation to meet the requirements in NRC's regulations pertaining to earthquake engineering criteria for nuclear power plants. The ground motion data recorded by free-field seismic instrumentation are used to compare the actual earthquake motion at the site with the design input motion. The result of the comparison determines whether the Operating Basis Earthquake ground motion (OBE) has been exceeded and plant shutdown is required, NRC (1997b). The free-field is defined as a location on the ground surface or in the site soil column that is sufficiently distant from the site structures to be essentially unaffected by the vibration of the site structures.

Soil-structure interaction (SSI) analyses were performed to estimate the location at which the SSI response approximates the free-field. Responses at points in the soil/rock were calculated at the free surface of soil/rock and at foundation depth, and compared with the specified free-field ground motions. Variables in the SSI analyses include: nuclear power plant configurations, site conditions, recorded time history ground motions, and excitation levels. Although significant variability in the data exists, generally, seismic instrumentation located one-diameter distance from the edge of the structure/foundation is adequate to meet the acceptance criteria of median (50\% NEP) observer response spectra values being within $10 \%$ of those of the input motion for all frequencies less than $50 \mathrm{~Hz}$.

\section{INTRODUCTION}

This paper describes the technical approach, soil-structure models, soil-structure interaction (SSI) analyses, and the results of the analyses to estimate the location at which the SSI response approximates the free-field. Soil-structure interaction (SSI) analyses were performed with the SASSI family of computer programs for simplified models of soil/rock and structures. The responses at points in the soil/rock were calculated at the free surface of soil/rock and at foundation depth. These responses were compared with the specified free-field ground motions to provide guidance on the location of free-field seismic instrumentation at nuclear power plant sites to minimize the effects of structure vibrations on the recorded motions. The comparisons are in terms of response spectra at 5\% damping. Three generic site conditions were considered: a rock site, a deep soil site, and a layered site. Ground motions for the analyses were substantially based on recorded earthquake ground motions correlated with earthquake magnitude and distance parameters typical of governing values derived from past probabilistic seismic hazard assessments (PSHAs). The ground motions for each site condition were defined by seven recorded acceleration time histories judged to be appropriate for the site conditions. Two excitation levels were considered. Statistics of the results were used for comparison with the free-field ground motion. Three nuclear power plant configurations were evaluated: Westinghouse AP1000, AREVA EPR, and GE ABWR. These three configurations are diverse in their foundation and structure configurations, and dynamic behavior. Results indicate stability in the specification of distances from the foundation to the location where the motion approximates that of the free-field expressed as a function of foundation 
dimensions. A complete description of the SSI analyses and results are provided in "Revision of Regulatory Guidance for Nuclear Power Plant Instrumentation for Earthquakes: SSI Analyses to Determine Free-Field Location," Johnson et al. (2012).

\section{SITE CONDITIONS}

The selection of site conditions and ground motions to be analyzed are strongly correlated. The basis for specification of the site conditions for this study was the twenty-eight existing Central and Eastern US sites for which numerous studies have been performed, such as those documented in EPRI and DOE (2005). In summary, of the twenty-eight sites, thirteen are denoted rock, five are denoted rock with surficial soil identified, and the remaining ten are denoted soil of various thicknesses. Three generic site conditions were considered for this study: a rock site, a deep soil site, and a layered site.

The rock site was modeled as a uniform half-space with a shear wave velocity (Vs) of 6,000 fps.

The deep soil site was modeled with a smoothly varying set of soil properties. The near surface shear wave velocity was defined to be $1,000 \mathrm{fps}$, with a shear modulus that varied proportionally with the square root of the depth in the soil.

The layered site was modeled as a 130-ft layer of soil overlying stiff bedrock. This site is patterned after the Electric Power Research Institute (EPRI) site designation of Soil III, which is defined to be a soil layer (thickness 80 to $180 \mathrm{ft}$.) over bedrock. The properties of the soil layer were the same as those at corresponding depths in the deep soil model, with an average Vs of about $2000 \mathrm{fps}$; the properties in the underlying rock half-space were the same as those for the rock site (Vs of $6000 \mathrm{fps}$ ).

The discretization of the site models was the same for all three site conditions, with the deep soil site shear wave velocities controlling the model layer thicknesses. These thicknesses were selected so that each layer could transmit at least $40 \mathrm{~Hz}$ in the horizontal direction at a discretization of 5 layers per wave length. Most layers could transmit almost $50 \mathrm{~Hz}$ at that discretization; the average was about $47 \mathrm{~Hz}$.

Site properties other than shear wave velocity (and corresponding moduli) were held constant for all soil layers for each set of analyses. The mass density was taken as $0.004 \mathrm{k}-\mathrm{sec}^{2} / \mathrm{ft}^{4}$ (unit weight 0.1288 kcf) in both soil and rock. Poisson's ratio was taken as 0.25 .

The site properties discussed above (shear modulus, Poisson's ratio, density) were held constant for each excitation level and ground motion time history in the SSI analyses. The parameter that changed with excitation level was material damping. For the three site profiles, material damping varied with excitation level. However, material damping was constant as a function of supporting material type (soil or rock) for each excitation level and each time history.

\section{GROUND MOTIONS}

Ground motions for the SSI analyses were based on the site condition being analyzed and the objective of encompassing different frequency content as a function of magnitude and distance from the nuclear power plant site. For each site condition, two loading conditions were defined, i.e., ground motion acceleration levels that span the range of earthquakes less than and greater than the OBE for the twenty-eight sites. This range of earthquakes attempts to account for the seismic hazard differences over the geographical extent of the central and eastern US. For each of these loading levels, seven ground motion time histories were specified for analysis. Numerous sensitivity studies were performed to assess the effects of varying material damping in the soil and rock. For the rock and layered site conditions, fourteen analyses were performed. For the deep soil site condition, an additional case of seven analyses was analyzed to further assess the effect of material damping on the conclusions.

The horizontal peak ground acceleration (PGA) levels at the ground surface selected for the two excitation levels were $0.08 \mathrm{~g}$ for the lower level case and $0.25 \mathrm{~g}$ for the higher level case.

NRC provided the earthquake acceleration ground motion time histories for the study. For the rock and deep soil sites, seven sets of three components of recorded motions were provided. From each of the sets, one horizontal component was selected for the SSI analyses. 
Time history and response spectra plots for each of the selected components for the rock site analyses were reviewed. All seven have significant high frequency content, i.e., peak spectral accelerations at frequencies above $20 \mathrm{~Hz}$. and in some cases up to $50 \mathrm{~Hz}$. Many of the time histories exhibit peaks at frequencies less than $10 \mathrm{~Hz}$, but generally less in amplitude than the high frequency peaks.

For the deep soil site, generally the peak spectral accelerations occur in the low frequency range, i.e., less than $10 \mathrm{~Hz}$. There were two exceptions; a record from the Chalfant Valley earthquake recorded at Zach Brothers Ranch Station where approximately the same peak spectral acceleration occurs at about $8.5 \mathrm{~Hz}$. and $12 \mathrm{~Hz}$, and a record from the Mammoth Lakes earthquake recorded at Convict Creek Station where the peak spectral acceleration occurs at about $12 \mathrm{~Hz}$. and is equal to about $4 \mathrm{~g}$; a peak in the low frequency range also occurs at about $4 \mathrm{~Hz}$. with amplitude of $2.7 \mathrm{~g}$.

For the rock and deep soil sites, the same selected seven time histories were used for the lower level and higher level excitations scaled to PGA values of $0.08 \mathrm{~g}$ and $0.25 \mathrm{~g}$ respectively.

For the layered site condition, NRC performed site response analyses for the two excitation levels to generate free-field motion at the top of grade. The site response analyses were performed for randomized soil columns excited by horizontal ground motion time histories on the rock outcrop at a depth of $130 \mathrm{ft}$. The resulting top of grade free surface time histories were provided to this effort and scaled to PGA values of $0.08 \mathrm{~g}$ for the lower level excitation and $0.25 \mathrm{~g}$ for the higher level of excitation. Generally, the peak spectral accelerations occur in the low frequency range reflecting the frequency of the soil layer over rock. However, in many cases there are high frequency peaks, i.e., at frequencies greater than $10 \mathrm{~Hz}$. in addition to those in the low frequency range.

\section{STRUCTURE MODELS}

\section{Westinghouse AP1000 Advanced Reactor Design}

The frequencies and masses representative of the AP1000 advanced reactor design were derived from the SSI analyses described in EPRI and DOE (2006), NRC (2006), and AP1000 (2007).

\section{Structure Stick Model}

The simplified structure model consists of three concentric sticks representing the Coupled Auxiliary and Shield Building (ASB), the Steel Containment Vessel (SCV), and the Containment Internal Structure (CIS). The three sticks are coupled at various locations. The model does not exactly match the AP1000 fundamental frequencies and mode shapes due to the simplifications and generalizations made in creating the example structure. However, the goal was to utilize a representative nuclear structure and not to model any particular new plant design; therefore, the model is considered to be adequate.

The dynamic properties of the structure were represented as a set of four single-degree-of-freedom (SDOF) systems, modeling four major modes. Since the study is only concerned with motions in a single horizontal direction, only modes in the X-direction were considered. Three SDOF models represented modes with predominant contributions from the ASB, the CIS and the $\mathrm{SCV}$, respectively. One SDOF model had significant contributions from all three sub-structures (ASB, CIS, SCV). The masses of the SDOF systems were derived from the mass participation of these modes in the detailed finite element model. The SDOF systems were located vertically in the SSI model such that the rocking effects of their modes were correctly modeled.

The remaining structure mass or missing mass not modeled by these SDOF models was included as a concentrated mass located vertically such that it properly simulated the horizontal translation and rocking effects of the structure about the foundation.

\section{Foundation}

The area, thickness, and embedment of the Nuclear Island foundation is obtained directly or derived from AP1000 (2007). The thickness is $6 \mathrm{ft}$, the area of the footprint is about $32,915 \mathrm{ft}^{2}$, and the 
embedment depth is $39.5 \mathrm{ft}$. The side of an equivalent square having the same area is $181.42 \mathrm{ft}$ (one-half side is $90.71 \mathrm{ft}$ ). The embedment ratio is 0.44 for an equivalent square. The foundation mass is about $920 \mathrm{k}-\mathrm{sec}^{2} / \mathrm{ft}$. The foundation was assumed to be a $180 \mathrm{ft}$ square, $6 \mathrm{ft}$ thick structure, embedded $40 \mathrm{ft}$ and behaving rigidly. The study assumed two axes of symmetry about the $\mathrm{x}$ - and $\mathrm{y}$ - axes for computational efficiencies.

\section{AREVA U.S. EPR Advanced Reactor Design}

The frequencies and masses used to represent the AREVA U.S. advanced reactor design were derived from AREVA (2007) supplemented with mass information supplied by the NRC.

\section{Nuclear Island Structures}

The Nuclear Island (NI) Common Basemat Structures consist of ten buildings that share one common basemat. The NI common basemat supports the Reactor Building (RB) comprised of the Reactor Containment Building (RCB), Reactor Building Internal Structures (RBIS), and outer Reactor Shield Building (RSB); Safeguard Buildings (SB) 1 through 4; Fuel Building (FB); SBs 2 and 3 shield structure; FB shield structure; as well as the main steam valve stations (MSVS); the Vent Stack (VS); and the staircase towers (SCT). Safeguards Buildings 2 and 3 are separate structures that share a common wall. The RB occupies the central portion of the NI common basemat and houses the reactor coolant system (RCS). The main steam system (MSS) and main feedwater system valve stations are located within SBs 1 and 4. The SCTs are reinforced concrete structures located at the perimeter of the RSB. The SCTs are located in the areas where the footprints of the SBs and the FB overlap.

Except for electrical and mechanical system tie-ins, the NI Common Basemat Structures are structurally isolated from adjacent structures.

\section{$\underline{\text { Stick Models for NI Common Basemat Structures }}$}

Nine sticks, divided into three groups, represent the NI Common Basemat Structures supported on the common basemat. The three stick groups are:

- $\quad$ Stick-1T (or Stick 1) for the RBIS,

- Stick-3T (or Stick 3) for the RCB, and

- Stick-2T (or Stick 2) for the seven balance-of-NI Common Basemat Structures including Stick 2 for the RSB, Stick 4 for SB 1, Stick 5 for SBs 2 and 3, Stick 6 for SBs 2 and 3 shield structure, Stick 7 for SB 4, Stick 8 for FB and Stick 9 for FB shield structure.

\section{Basemat}

The footprint of the NI Common Basemat is similar to a cross; being about $357.61 \mathrm{ft}$ wide in the global X-direction and about $341.2 \mathrm{ft}$ long in the global Y-direction. The basemat is approximately 10 feet thick transitioning to thickened sections up to 13 feet in some locations. The area of the footprint is approximately $77,339 \mathrm{ft}^{2}$. The radius of an equivalent circle having the same area is $156.82 \mathrm{ft}$. The side of an equivalent square having the same area is $278.10 \mathrm{ft}$ (one-half side is $139.05 \mathrm{ft}$ ). The maximum depth of embedment of the NI Common Basemat is $41.34 \mathrm{ft}$. The portions of the NI Common Basemat adjacent to the NAB and Access Building are only slightly embedded. The foundation was assumed to be a $280 \mathrm{ft}$ square structure, rigidly embedded $40 \mathrm{ft}$.

\section{Advanced Boiling Water Reactor (ABWR)}

The frequencies and masses representative of the ABWR advanced boiling water reactor design were derived from the modal extraction analysis of a detailed finite element model of the Kashiwazaki-Kariwa (K-K) Nuclear Power Station, Unit 7, Reactor Building. A detailed description of the structure and its foundation is found in IAEA (2011). 
Structure Stick Model

For the purposes of the current study, the dynamic properties of the structure were represented as a set of four single-degree-of-freedom (SDOF) systems, modeling four major modes. Since the study is only concerned with motions in a single horizontal direction, only modes in the model X-direction were considered. The masses of the SDOF systems were derived from the mass participation of these modes in the detailed finite element model. The SDOF systems were located vertically in the SSI model such that the rocking effects of their modes were correctly modeled.

The remaining structure mass or missing mass not modeled by these SDOF models was included as a concentrated mass located vertically such that it properly simulated the horizontal translation and rocking effects of the structure about the foundation.

\section{Foundation}

The foundation of the K-K Unit 7 Reactor Building consists of an 18-ft thick rectangular basemat about $185 \mathrm{ft} \times 195 \mathrm{ft}$. The area of the footprint is $36,310 \mathrm{ft}^{2}$. The side of an equivalent square having the same area is $190.55 \mathrm{ft}$ (one-half side is $95.28 \mathrm{ft}$ ). The foundation is embedded about 85 feet, giving an embedment ratio of 0.90 . However, the top 25 feet of the soil profile was estimated to be extremely soft during seismic excitation so that the effective embedment is considered to be about $60 \mathrm{ft}$, giving an embedment ratio of about 0.62 . The foundation mass is about $3,480 \mathrm{k}-\mathrm{sec}^{2} / \mathrm{ft}$. For the purpose of the present study the foundation was assumed to be a $180 \mathrm{ft}$ square, $18 \mathrm{ft}$ thick, embedded 57.5 feet and behaving rigidly. The present study assumed two axes of symmetry about the $\mathrm{x}$ - and $\mathrm{y}$-axes for computational efficiencies.

\section{SOIL-STRUCTURE INTERACTION ANALYSES}

\section{SSI Analyses - Three soil Profiles}

\section{$\underline{\text { General }}$}

The SSI analyses were performed with SASSI incorporating the soil/rock models described in the section "Site Conditions," the structure models described in the section "Structural Models," and input ground motion time histories described in the section "Ground Motion."

Two excitation levels were considered with PGA values of $0.08 \mathrm{~g}$ and $0.25 \mathrm{~g}$. The difference in the SASSI models as a function of the excitation levels was material damping in the soil and structure. For the rock and layered soil sites, two cases were analyzed. For the AP1000 model founded on the deep soil site, an additional case for a reduced value of material damping in the soil was considered for the higher excitation level, i.e., material damping in the soil of a constant $3.5 \% \mathrm{vs}$. $7 \%$ to assess the effects of material damping on the overall results.

Numerous sensitivity studies were performed. Seven SSI analyses were executed for each combination of site condition and excitation level. For each analysis, time histories were calculated at each of the free-field observation points and compared with the spectrum of the free-field input motion.

\section{Free-Field Observation Points}

Free-field observation points were included in the SASSI model as pairs of nodes situated at the ground surface and at the bottom of foundation level at varying distances from the foundation along the axis of excitation. These nodes were not connected to other portions of the model, but were included in the analyses as interaction nodes so that response could be calculated at their locations. The nodes were located at distances of 100,120,150,180, 200,300,400, 600, 800 and $1000 \mathrm{ft}$ from the centerline of the model. These distances are 10,30,60, 90, 110, 210,310, 510, 710 and $910 \mathrm{ft}$ from the edge of the modeled foundation, respectively. 


\section{SASSI Model}

The SASSI models for the three plant cases were basically constructed the same. Each was comprised of a number of components. Each component of the model is discussed.

\section{Foundation and Excavated Soil}

For each plant the foundation was assumed to be square (symmetric in both horizontal directions) with its origin at its center, so that it could be modeled as a quarter model. Each quarter model was comprised of brick elements modeling the excavated soil, rigid plate elements modeling the exterior foundation walls and base, and an assembly of rigid beam elements and flexible spring elements modeling the dynamic characteristics of the structure.

The AP1000 and ABWR foundations were modeled as $90-\mathrm{ft} \times 90-\mathrm{ft}$ quarter models using fifteen 6 - $\mathrm{ft}$ x 6-ft elements in each horizontal direction; a total of 225 elements horizontally. The AP1000 model had 6 layers vertically, selected to coincide with the soil layering in the site models. Element sizes varied from $8 \mathrm{ft}$ at the foundation base to $5 \mathrm{ft}$ at grade, for a total embedment of 40 feet. The ABWR model had the same element geometry as the AP1000 but had two additional layers of $8.5 \mathrm{ft}$ and $9 \mathrm{ft}$ to extend the foundation embedment depth to $57.5 \mathrm{ft}$.

The EPR foundation was modeled as a $140-\mathrm{ft}$ x 140 - $\mathrm{ft}$ quarter model using twenty-four square $(5.833 \mathrm{ft} \times 5.833 \mathrm{ft})$ elements in each horizontal direction. It had the same vertical layer discretization as the AP1000 model so that it had an embedment of $40 \mathrm{ft}$.

The horizontal discretization of the brick elements was such that they were capable of passing about $21 \mathrm{~Hz}$ at grade to about $43 \mathrm{~Hz}$ at basemat level at 8 elements per wavelength $(33 \mathrm{~Hz}$ and $68 \mathrm{~Hz}$ at 5 elements per wavelength).

For all SASSI models, the material properties of all plate elements were such that the foundation behaved rigidly. Six rigid beam elements were also used to provide additional stiffness to ensure rigid behavior of the exterior walls and base. Rigid behavior was verified through sensitivity studies.

\section{Structure Models}

The SDOF models were constructed of rigid vertical beams, with spring-mass assemblies attached, extending from the foundation to appropriate elevations to model the modal heights. Additional beam elements were used to ensure rigid-body motion of the vertical beams. The spring-mass assemblies were tuned to the appropriate fixed-base structure modes.

Modal damping for the SDOF structure models follows the guidelines in ASCE/SEI (2005) for Response Levels 1 and 2. For the low free-field excitation level, modal damping was taken to be $4 \%$ for predominantly reinforced concrete structures, and $2 \%$ for predominantly steel structures. For the high free-field excitation level, modal damping was taken as $7 \%$ and $4 \%$.

\section{DISCUSSION OF RESULTS}

Data of calculated response spectra at observer locations and the response spectra of the input ground motion time histories were processed according to several criteria to permit interpretation: (1) Direct response spectra (5\% damping) comparisons; (2) Normalized differences; (3) Root mean square (RMS) differences; (4) Average absolute values of differences; and (5) Tabulation of the distance and corresponding frequency to achieve an accuracy of $5 \%$ and $10 \%$ in the response spectra comparisons, Johnson et al. (2012).

\section{Distance and Frequency to Achieve 5\% and 10\% Accuracy - AP1000}

The following is an example of an approach to interrogate AP1000 data to determine the governing distance and corresponding frequency to achieve accuracy within $5 \%$ or $10 \%$ between the response 
spectra of the motions at the observer locations compared to the response spectra of the input ground motion time histories. Error! Reference source not found.s 1 through 3 show these results as a function of site condition; each contains results for the top of grade and basemat level. Site conditions were treated separately, since initial evaluations showed site conditions to be a potentially important discriminator. The remaining data was treated as one data set, i.e., responses as a function of excitation level and input time histories were treated as one data set. The following parameters were derived from each data set: (1) Envelope case, i.e., the minimum frequency at each distance from the centerline (or edge of the basemat); (2) 84\% non-exceedance probability level (NEP); and (3) Median value.

Each table lists, for a given distance from the foundation, the maximum frequency below which the spectra of all points, $84 \%$ of the points, or half of the points further away from the foundation differ at most by the criterion, i.e., within $5 \%$ or $10 \%$.

\section{Results for AP1000 Rock Case (Table 1)}

Generally, one can achieve accurate results at frequencies less than $10 \mathrm{~Hz}$ even with seismic instrumentation placed very close to the structure/foundation, i.e., within tens of feet of the foundation edge. Note that four of the seven rock input ground motions possessed significant frequency content in the frequency range less than $10 \mathrm{~Hz}$.

\section{Table 1: AP1000, Frequencies at Which The Observer Response is Within 5\% and 10\% of the Input Time History Response Spectra; Envelope is The Minimum Over The Ground Motion Set; Grade and Basemat Level; Rock Site}

\begin{tabular}{|c|c|c|c|c|c|c|c|c|c|c|c|}
\hline \multirow[b]{4}{*}{ Rock } & \multicolumn{11}{|c|}{$\begin{array}{l}\text { Grade Elevation } \\
\text { Distance from Foundation (ft) }\end{array}$} \\
\hline & From CL & 100 & 120 & 150 & 180 & 200 & 300 & 400 & 600 & 800 & 1000 \\
\hline & From Edge & 10 & 30 & 60 & 90 & 110 & 210 & 310 & 510 & 710 & 910 \\
\hline & \multicolumn{11}{|c|}{ Frequency $(\mathrm{Hz})$} \\
\hline \multirow{3}{*}{$\begin{array}{l}\text { Within } \\
5 \%\end{array}$} & Envelope & 9.0 & 9.8 & 9.8 & 28.6 & 28.6 & 34.4 & 34.4 & $>50.0$ & $>50.0$ & $>50.0$ \\
\hline & $84 \%$-ile & 9.4 & 9.8 & 28.6 & 28.6 & 31.4 & 34.4 & $>50.0$ & $>50.0$ & $>50.0$ & $>50.0$ \\
\hline & Median & 9.8 & 10.3 & 31.4 & 32.1 & 35.2 & 45.5 & $>50.0$ & $>50.0$ & $>50.0$ & $>50.0$ \\
\hline \multirow{3}{*}{$\begin{array}{l}\text { Within } \\
10 \%\end{array}$} & Envelope & 9.8 & 18.8 & 41.4 & 41.4 & $>50.0$ & $>50.0$ & $>50.0$ & $>50.0$ & $>50.0$ & $>50.0$ \\
\hline & $84 \%$-ile & 10.3 & 20.7 & $>50.0$ & $>50.0$ & $>50.0$ & $>50.0$ & $>50.0$ & $>50.0$ & $>50.0$ & $>50.0$ \\
\hline & Median & 12.7 & 22.2 & $>50.0$ & $>50.0$ & $>50.0$ & $>50.0$ & $>50.0$ & $>50.0$ & $>50.0$ & $>50.0$ \\
\hline
\end{tabular}

\begin{tabular}{|c|c|c|c|c|c|c|c|c|c|c|c|}
\hline \multirow[b]{4}{*}{ Rock } & \multicolumn{11}{|c|}{$\begin{array}{c}\text { Basemat Elevation } \\
\text { Distance from Foundation (ft) } \\
\end{array}$} \\
\hline & From CL & 100 & 120 & 150 & 180 & 200 & 300 & 400 & 600 & 800 & 1000 \\
\hline & From Edge & 10 & 30 & 60 & 90 & 110 & 210 & 310 & 510 & 710 & 910 \\
\hline & \multicolumn{11}{|c|}{ Frequency $(\mathrm{Hz})$} \\
\hline \multirow{3}{*}{$\begin{array}{l}\text { Within } \\
5 \%\end{array}$} & Envelope & 9.8 & 9.8 & 9.8 & 9.8 & 26.1 & 30.0 & 43.4 & $>50.0$ & $>50.0$ & $>50.0$ \\
\hline & $84 \%$-ile & 10.3 & 10.3 & 28.6 & 28.6 & 30.0 & 32.9 & $>50.0$ & $>50.0$ & $>50.0$ & $>50.0$ \\
\hline & Median & 24.9 & 28.6 & 31.4 & 31.4 & 31.4 & 41.4 & $>50.0$ & $>50.0$ & $>50.0$ & $>50.0$ \\
\hline \multirow{3}{*}{$\begin{array}{l}\text { Within } \\
10 \%\end{array}$} & Envelope & 24.9 & 30.0 & 32.9 & 32.9 & 32.9 & 37.8 & $>50.0$ & $>50.0$ & $>50.0$ & $>50.0$ \\
\hline & $84 \%$-ile & 28.6 & 30.0 & 36.1 & 37.8 & 41.4 & $>50.0$ & $>50.0$ & $>50.0$ & $>50.0$ & $>50.0$ \\
\hline & Median & 30.7 & 34.4 & 40.5 & 41.4 & 44.4 & $>50.0$ & $>50.0$ & $>50.0$ & $>50.0$ & $>50.0$ \\
\hline
\end{tabular}

For frequencies greater than $10 \mathrm{~Hz}$, seismic instrumentation needs to be located at larger distances from the structure/foundation. The results differ depending on the location of the instrumentation, i.e., at grade level or level of the embedded basemat.

- At grade level, assuming a 50\% NEP (median) level as the acceptance criteria, one can achieve accuracy within $10 \%$ for all frequencies less than $50 \mathrm{~Hz}$ by placing instrumentation $150 \mathrm{ft}$ or greater from the centerline of this nuclear island (or $60 \mathrm{ft}$ from the structure/foundation edge). 
- At basemat level in the free-field, assuming a 50\% NEP (median) level as the acceptance criteria, one can achieve accuracy within $10 \%$ for all frequencies less than about $50 \mathrm{~Hz}$ by placing instrumentation about $300 \mathrm{ft}$ or greater from the centerline of this nuclear island (or $210 \mathrm{ft}$ from the structure/foundation edge).

Results for AP1000 Deep Soil Case (Table 2)

The results differ depending somewhat on the location of the instrumentation, i.e., at grade level or level of the embedded basemat.

At grade level, assuming a 50\% NEP (median) level as the acceptance criteria, one can achieve accuracy within $10 \%$ for frequencies less than about $10 \mathrm{~Hz}$ by placing instrumentation possibly as close as $150 \mathrm{ft}$ from the nuclear island centerline (or $60 \mathrm{ft}$ from the edge of the structure/foundation). To achieve similar levels of accuracy for frequencies less than $50 \mathrm{~Hz}$, instrumentation placed at $200 \mathrm{ft}$ from the centerline (or $110 \mathrm{ft}$ from the edge of the structure/foundation) is adequate.

At basemat level in the free-field, for frequencies less than $10 \mathrm{~Hz}$, the $50 \%$ NEP (median) level acceptance criteria is achieved very close to the structure/foundation. For frequencies less than $50 \mathrm{~Hz}$, the same accuracy is achieved by placing the instrumentation at a distance of $300 \mathrm{ft}$ from the centerline (or $210 \mathrm{ft}$ from the structure/foundation edge). In this case, Table 2 shows that all acceptance criteria for within $10 \%$ (median, $84 \%$ NEP, and envelope) are met at the distance of $300 \mathrm{ft}$ from the centerline.

Table 2: AP1000, Frequencies at Which The Observer Response is Within 5\% and $10 \%$ of the Input Time History Response Spectra; Envelope is The Minimum Over The Ground Motion Set; Grade and Basemat Level; Deep Soil Site

\begin{tabular}{|c|c|c|c|c|c|c|c|c|c|c|c|}
\hline \multirow{4}{*}{$\begin{array}{l}\text { Deep } \\
\text { Soil }\end{array}$} & \multicolumn{11}{|c|}{$\begin{array}{l}\text { Grade Elevation } \\
\text { Distance from Foundation (ft) }\end{array}$} \\
\hline & From CL & 100 & 120 & 150 & 180 & 200 & 300 & 400 & 600 & 800 & 1000 \\
\hline & From Edge & 10 & 30 & 60 & 90 & 110 & 210 & 310 & 510 & 710 & 910 \\
\hline & \multicolumn{11}{|c|}{ Frequency $(\mathrm{Hz})$} \\
\hline \multirow{3}{*}{$\begin{array}{l}\text { Within } \\
5 \%\end{array}$} & Envelope & 2.3 & 2.7 & 5.1 & 7.5 & 7.5 & 8.2 & 8.2 & 14.9 & $>50.0$ & $>50.0$ \\
\hline & $84 \%$-ile & 2.3 & 2.9 & 6.2 & 7.8 & 7.8 & 8.6 & 8.6 & $>50.0$ & $>50.0$ & $>50.0$ \\
\hline & Median & 2.8 & 3.2 & 7.5 & 8.2 & 8.2 & 11.6 & 11.6 & $>50.0$ & $>50.0$ & $>50.0$ \\
\hline \multirow{3}{*}{$\begin{array}{l}\text { Within } \\
10 \%\end{array}$} & Envelope & 2.9 & 5.1 & 9.8 & 9.8 & 13.0 & 13.0 & $>50.0$ & $>50.0$ & $>50.0$ & $>50.0$ \\
\hline & $84 \%$-ile & 3.1 & 5.1 & 9.8 & 9.8 & 14.3 & 14.3 & $>50.0$ & $>50.0$ & $>50.0$ & $>50.0$ \\
\hline & Median & 3.4 & 6.2 & 10.6 & 10.6 & $>50.0$ & $>50.0$ & $>50.0$ & $>50.0$ & $>50.0$ & $>50.0$ \\
\hline
\end{tabular}

Basemat Elevation

Distance from Foundation (ft)

\begin{tabular}{|c|c|c|c|c|c|c|c|c|c|c|c|}
\hline \multirow{4}{*}{$\begin{array}{l}\text { Deep } \\
\text { Soil }\end{array}$} & \\
\hline & From CL & 100 & 120 & 150 & 180 & 200 & 300 & 400 & 600 & 800 & 1000 \\
\hline & From Edge & 10 & 30 & 60 & 90 & 110 & 210 & 310 & 510 & 710 & 910 \\
\hline & \multicolumn{11}{|c|}{ Frequency $(\mathrm{Hz})$} \\
\hline \multirow{3}{*}{$\begin{array}{l}\text { Within } \\
5 \%\end{array}$} & Envelope & 1.9 & 4.9 & 5.1 & 8.2 & 8.2 & 9.4 & 9.4 & 11.3 & $>50.0$ & $>50.0$ \\
\hline & $84 \%$-ile & 5.1 & 5.1 & 7.8 & 9.0 & 9.0 & 11.3 & 11.3 & $>50.0$ & $>50.0$ & $>50.0$ \\
\hline & Median & 7.6 & 7.8 & 9.0 & 9.4 & 10.4 & $>50.0$ & $>50.0$ & $>50.0$ & $>50.0$ & $>50.0$ \\
\hline \multirow{3}{*}{$\begin{array}{l}\text { Within } \\
10 \%\end{array}$} & Envelope & 8.6 & 8.6 & 9.0 & 9.0 & 9.0 & $>50.0$ & $>50.0$ & $>50.0$ & $>50.0$ & $>50.0$ \\
\hline & $84 \%$-ile & 9.0 & 9.0 & 10.3 & 10.3 & 10.3 & $>50.0$ & $>50.0$ & $>50.0$ & $>50.0$ & $>50.0$ \\
\hline & Median & 11.9 & 11.9 & 13.5 & 16.0 & 16.5 & $>50.0$ & $>50.0$ & $>50.0$ & $>50.0$ & $>50.0$ \\
\hline
\end{tabular}

Results for AP1000 Layered Soil Case (Table 3)

At grade level, assuming a 50\% NEP (median) level as the acceptance criteria, one can achieve accuracy within $10 \%$ for frequencies less than about $10 \mathrm{~Hz}$ by placing instrumentation as close as $180 \mathrm{ft}$ from the nuclear island centerline (or $90 \mathrm{ft}$ from the edge of the structure/foundation). To achieve similar 
levels of accuracy for frequencies less than $50 \mathrm{~Hz}$, instrumentation placed at $400 \mathrm{ft}$ from the centerline (or $310 \mathrm{ft}$ from the edge of the structure/foundation) is adequate.

At basemat level in the free-field, accuracy for frequencies less than about $10 \mathrm{~Hz}$ is indicated to be achieved with instrumentation very close to the structure/foundation. For frequencies less than $50 \mathrm{~Hz}$, the same accuracy is achieved by placing the instrumentation at a distance of $180 \mathrm{ft}$ from the centerline (or $90 \mathrm{ft}$ from the structure/foundation edge).

Table 3: AP1000, Frequencies at Which The Observer Response is Within 5\% and 10\% of the Input Time History Response Spectra; Envelope is The Minimum Over The Ground Motion Set; Grade and Basemat Level; Layered Soil Site

\begin{tabular}{|c|c|c|c|c|c|c|c|c|c|c|c|}
\hline \multirow{4}{*}{$\begin{array}{l}\text { Layered } \\
\text { Soil }\end{array}$} & \multicolumn{11}{|c|}{$\begin{array}{l}\text { Grade Elevation } \\
\text { Distance from Foundation }(\mathbf{f t})\end{array}$} \\
\hline & From CL & 100 & 120 & 150 & 180 & 200 & 300 & 400 & 600 & 800 & 1000 \\
\hline & From Edge & 10 & 30 & 60 & 90 & 110 & 210 & 310 & 510 & 710 & 910 \\
\hline & \multicolumn{11}{|c|}{ Frequency $(\mathrm{Hz})$} \\
\hline \multirow{3}{*}{$\begin{array}{l}\text { Within } \\
5 \%\end{array}$} & Envelope & $<1.0$ & $<1.0$ & 5.1 & 7.5 & 7.5 & 8.2 & 11.9 & 14.3 & $>50.0$ & $>50.0$ \\
\hline & $84 \%$-ile & $<1.0$ & 2.9 & 5.1 & 7.8 & 7.8 & 10.8 & 14.3 & 15.7 & $>50.0$ & $>50.0$ \\
\hline & Median & 2.9 & 4.0 & 6.2 & 8.6 & 8.8 & 11.9 & 17.2 & $>50.0$ & $>50.0$ & $>50.0$ \\
\hline \multirow{3}{*}{$\begin{array}{l}\text { Within } \\
10 \%\end{array}$} & Envelope & $<1.0$ & 5.1 & 8.2 & 8.2 & 8.2 & 11.3 & 18.8 & $>50.0$ & $>50.0$ & $>50.0$ \\
\hline & $84 \%$-ile & 2.9 & 5.4 & 9.0 & 9.0 & 9.4 & 12.4 & $>50.0$ & $>50.0$ & $>50.0$ & $>50.0$ \\
\hline & Median & 4.3 & 7.0 & 9.8 & 10.1 & 21.1 & 24.4 & $>50.0$ & $>50.0$ & $>50.0$ & $>50.0$ \\
\hline
\end{tabular}

Basemat Elevation

Distance from Foundation (ft)

\begin{tabular}{|c|c|c|c|c|c|c|c|c|c|c|c|}
\hline \multirow{3}{*}{$\begin{array}{l}\text { Layered } \\
\text { Soil }\end{array}$} & From CL & 100 & 120 & 150 & 180 & 200 & 300 & 400 & 600 & 800 & 1000 \\
\hline & From Edge & 10 & 30 & 60 & 90 & 110 & 210 & 310 & 510 & 710 & 910 \\
\hline & \multicolumn{11}{|c|}{ Frequency (Hz) } \\
\hline \multirow{3}{*}{$\begin{array}{l}\text { Within } \\
5 \%\end{array}$} & Envelope & 2.3 & 2.3 & 2.9 & 7.8 & 8.2 & 9.8 & 10.8 & 10.8 & $>50.0$ & $>50.0$ \\
\hline & $84 \%$-ile & 3.6 & 3.6 & 6.2 & 8.6 & 9.8 & 10.8 & 11.3 & 11.3 & $>50.0$ & $>50.0$ \\
\hline & Median & 7.3 & 7.3 & 9.2 & 10.6 & 15.7 & 16.0 & 17.2 & $>50.0$ & $>50.0$ & $>50.0$ \\
\hline \multirow{3}{*}{$\begin{array}{l}\text { Within } \\
10 \%\end{array}$} & Envelope & 10.3 & 11.3 & 11.3 & 11.3 & 11.3 & 11.3 & 18.0 & $>50.0$ & $>50.0$ & $>50.0$ \\
\hline & $84 \%$-ile & 10.8 & 11.3 & 11.3 & 11.3 & 12.4 & 18.0 & $>50.0$ & $>50.0$ & $>50.0$ & $>50.0$ \\
\hline & Median & 11.6 & 13.9 & 16.8 & $>50.0$ & $>50.0$ & $>50.0$ & $>50.0$ & $>50.0$ & $>50.0$ & $>50.0$ \\
\hline
\end{tabular}

\section{CONCLUSIONS}

The overall approach to investigating the location of seismic instrumentation to assure recording of free-field motion, minimally affected by structure vibrations during an earthquake was described. The approach was applied to three Certified Designs; representation of the Westinghouse AP1000, the AREVA EPR, and the GE ABWR. Three site conditions (rock, deep soil, and layered soil) were considered. Multiple ground motion simulations were applied, each ground motion selected to be reasonable for the site condition. The results were comparisons of free-field input ground response spectra to response spectra calculated at various distances from the nuclear island and derived quantities from these response spectra comparisons. Responses were calculated at top of grade elevation and at foundation depth and compared with the corresponding input data for the SSI analyses. The location at which the SSI response approaches that in the free-field is dependent on the Certified Design, site condition, the location of the instrument (grade or basemat level), the frequency range of interest, and the acceptance criteria.

The conclusions encompass all three Certified Designs. The most important conclusion of this study is: Although significant variability in the data exists, in all cases but three, seismic instrumentation located one-diameter distance from the edge of the structure/foundation is adequate to meet the 
acceptance criteria of median (50\% NEP) response being within $10 \%$ in observer location response spectra compared to the input time history for all frequencies less than $50 \mathrm{~Hz}$.

\section{REFERENCES}

AP1000 (2007). AP1000 Tier 2 Final Safety Analysis Report (Design Control Document), Chapter 3, Design of Structures, Components, Equipment, and Systems, (NRC ADAMS Accession No. ML071580882).

AREVA (2007). AREVA U.S. EPR Tier 2 Final Safety Analysis Report (Design Control Document), Revision 0, Section 3.7.2 (NRC ADAMS Accession No. ML073531458).

ASCE/SEI (2005). Seismic Design Criteria for Structures, Systems, and Components in Nuclear Facilities, ASCE/SEI 43-05, American Society of Civil Engineers, Structural Engineering Institute, 2005.

Johnson, James J., Maslenikov, Oleg R., and Kenneally, Roger M. (2012). Revision of Regulatory Guidance for Nuclear Power Plant Instrumentation for Earthquakes: SSI Analyses to Determine Free-Field Location, Volumes 1 and 2, Draft Report for Comment, James J. Johnson and Associates, Alamo, CA, for Information Systems Laboratories, Inc., 6 June 2012.

EPRI and DOE (2005). Program on Technology Innovation: Assessment of a Performance-Based Approach for Determining Seismic Ground Motions for New Plant Sites, V2: Volume 2: Seismic Hazard Results at 28 Sites. EPRI, Palo Alto, CA and U.S. Department of Energy, Germantown, MD: 2005. 1012045.

EPRI and DOE (2006). Effect of Seismic Wave Incoherence on Foundation and Building Response. EPRI, Palo Alto, CA and the U.S. Department of Energy: 2006 1013504, (NRC ADAMS Accession No. ML063000232),

IAEA (2011). Kashiwazaki-Kariwa Research Initiative for Seismic Margin Assessment, KARISMA Benchmark - Guidance Document, Part 1: K-K Unit 7 R/B Structure, Phase I, II \& III, Vienna, July 2011， IAEA-EBP-SS-WA2-KARISMA-SP-002， Revision 04， 12.07.2011， Restricted Distribution.

NRC (1997a). Regulatory Guide 1.12, Nuclear Power Plant Instrumentation for Earthquakes, Revision 2, U.S. Nuclear Regulatory Commission.

NRC (1997b). Regulatory Guide 1.166, Pre-Earthquake Planning and Immediate Nuclear Power Plant Operator Postearthquake Actions, U.S. Nuclear Regulatory Commission.

NRC (2006). NRC public meeting December 20-21, 2006 - EPRI presentation on New Plant Seismic Issues Resolution Program - Follow-up Discussions of S2.1 Incoherence Project.

\section{ACKNOWLEDGEMENT AND DISCLAIMER}

This study was sponsored by the Nuclear Regulatory Commission under NRC Contract Number NRC-04-07-113, Principal Contractor: Information Systems Laboratories. Neither the U.S. Government nor any agency thereof, nor any of their employees, makes any warranty, expressed or implied, or assumes any legal liability or responsibility for any third party's use, or the results of such use, of any information, apparatus, product, or process disclosed in this report, or represents that its use by such third party would not infringe privately owned rights. The views expressed in this paper are not necessarily those of the U.S. Nuclear Regulatory Commission and do not currently represent an agreed-upon NRC staff position.

The contributions of Bruce Mrowca and Jalal Zamanali, formerly affiliated with Information Systems Laboratories, are gratefully acknowledged. 